\title{
STUDIES WITH INAGGLUTINABLE ERYTHROCYTE COUNTS. V. SPONTANEOUS AND X-RAY-INDUCED HEMOLYSIS IN MALIGNANCY 1, 2
}

\author{
By RAYMOND F. SHEETS, HENRY E. HAMILTON, ELMER L. DEGOWIN, \\ AND CLINTON D. JANNEY \\ (From the Departments of Internal Medicine and Physiology, and the Radiation Research \\ Laboratory, State University of Iowa, Iowa City, Iowa)
}

(Submitted for publication April 16, 1953; accepted October 7, 1953)

Anemia in patients with malignant disease is currently ascribed (2) to blood loss, nutritional disturbances, metastases to the bone marrow, and, rarely, to failure of elaboration of the intrinsic factor of Castle. Slowly evidence is accumulating that a hemolytic mechanism also may be operable in many instances. In 1907, Weil (3) reported extensive experiments in which extracts of normal kidneys and livers of dogs produced slight and somewhat variable hemolysis of dogs' erythrocytes in vitro, but extracts of sarcomas and carcinomas were much more potent in their destruction of red blood cells. He also noted that extracts of necrotic portions of tumors were much more hemolytic than undegenerated tissues. Dogs' kidneys were exposed extraperitoneally, their pedicles ligated, and the organs replaced in the body. The resulting necrotic kidneys were recovered subsequently and extracts from them proved to be many times more hemolytic against dogs' erythrocytes in vitro than extracts of nomal dogs' kidneys.

Recently Gross (4) demonstrated hemolytic activity when filtrates of mouse mammary carcinoma were incubated with normal mouse erythrocytes. In a later paper (5) he reported that extracts of most human mammary cancer destroyed human erythrocytes of homologous blood group when they were incubated together for 48 hours at $38^{\circ} \mathrm{C}$. Carcinoma of the human stomach behaved similarly. Extracts of normal human breast, muscle, and thyroid gland produced no hemolysis under similar conditions. Ross, Crockett, and Emerson

\footnotetext{
1 Presented in part at the 24th Annual Meeting of the Central Society for Clinical Research, November 2, 1951 (1).

2 This work was supported in part by the Trust Fund of the Department of Internal Medicine and in part by the Medical Research and Development Board, Office of the Surgeon General, Department of the Army, under Contract No. DA-49-007-MD-485.
}

(6) reported a hemolytic mechanism as a large part of the cause of the anemia in leukemia and malignant lymphoma.

Clinicians have observed patients with carcinoma who did not develop anemia until they were subjected to roentgen therapy. Indirect evidence (7) has accumulated that irradiation can also cause a hemolytic anemia. The erythrocyte level in both animals and man falls faster after irradiation than can be accounted for if complete inhibition of erythropoiesis had occurred. Anemia may develop coincident with reticulocytosis. The bone marrow is known to be hyperplastic in the anemia caused by radium poisoning. The excretion of bile pigment is increased after the administration of large doses of $\mathrm{P}^{32}$ or total body $\mathrm{X}$ irradiation (8). In 1928, Heilmeyer (9) reported increased bile pigment excretion following local irradiation of uterin tumors in five patients.

There is little evidence to indicate the effects of direct irradiation on the red blood cell (10). Fricke and Petersen (11) found that it required 56,000 roentgens to convert hemoglobin to methemoglobin in 50 per cent aqueous solution. The osmotic fragility of erythrocytes is not affected by 400 milliampere hours of X-rays in vitro, and 33,000 roentgens are necessary to make the membranes of red blood cells permeable to magnesium. No reports have been found of human transfusion survival studies with erythrocytes irradiated in vitro.

The purpose of the present study was to investigate the mechanism of the anemia and the erythropoietic response in patients with carcinoma, some untreated and some receiving $\mathrm{X}$ irradiation.

\section{METHODS}

The data in these studies were obtained by application of the method described by DeGowin, Sheets, and Hamil- 
ton of Ashby's technique of differential agglutination of erythrocytes (12). The transfused erythrocytes were taken from normal donors. The donor's cells had previously been proved to survive normally in normal recipients. All donors belonged to group $\mathrm{O}$ and the recipients were either group $A$ or $O$. In one instance group $O N$ cells were given to a recipient who was group $\mathrm{O} M N$ and anti-M serum was used to agglutinate the recipient's erythrocytes. Each donor and recipient in a transfusion experiment belonged to compatible subtypes in the $R h$ system. Approximately $500 \mathrm{ml}$. of the donor's blood were collected in 3.2 per cent sodium citrate solution and stored at $4^{\circ} \mathrm{C}$. for less than 18 hours before transfusion. In most instances immediately before transfusion the cells were washed once in 0.9 per cent sodium chloride solution and resuspended in saline solution. Normal erythrocytes manipulated in this manner survive normally in a normal recipient. Before transfusion the concentration of donor's erythrocytes was counted and the volume of cell suspension was accurately measured.

Our methods of enumerating erythrocyte and inagglutinable cells have been reported and discussed in detail previously $(12,13)$.

Irradiation. Radium and $\mathrm{X}$-rays were used in the treatment of the patients with carcinoma of the cervix uteri in the manner generally employed in this hospital. A 200-K.V. machine was used for X-ray therapy with a Thoraeus filter giving a beam with a half value layer of 2 $\mathrm{mm}$. of copper. Six portals were employed routinely : two lateral portals, an anterior and a posterior portal, and two gluteal portals. Two hundred roentgens were given daily through each of two portals; consequently the daily dose in air was 400 roentgens. The total number of days of treatment with this dose was determined by the tumor dose desired. The daily $\mathrm{X}$-ray dose in air has been indicated in the figures because it is more objective than the calculated tumor dose and it is not known whether the effect observed on an erythrocyte was due to irradiation of normal or malignant tissue. Treatments were given six days a week.

Radium was applied to the cervical canal by means of the Ernst applicator and left in place for varying lengths of time. The usual total dose of radium was 5,000 to 7,000 mg. hrs., given in one to three periods. The total dose and the interval between exposures are indicated on the charts for each patient.

Selection of patients. Patients with carcinoma of the cervix uteri were selected who were to receive irradiation and who were not losing significant amounts of blood by hemorrhage. Patients with other types of malignancy were selected because of extensive disease and absence of hemorrhage.

\section{ANALYSIS OF DATA}

The derivation and proof of the analyses employed have been presented in the preceding paper (14). The experimental data consisted of the in- agglutinable erythrocyte counts of the transfused cells and the total cell counts taken simultaneously. The erythrocyte count of the patient at any time $t$ was computed by subtracting the inagglutinable cell count from the contemporaneous total cell count. The values for the observed inagglutinable cell counts and the patient's cell counts were plotted on Cartesian coordinates with cell counts on suitably scaled ordinates against time on the abscissa. Since fresh normal erythrocytes were transfused in all cases, it was assumed that the transfused cells had the same potential life span as those of the patient and that the observed destructive mechanism produced loss of the transfused cells at the same rate as those of the patient.

Demonstration of random loss of cells. The $N_{0} Q$ values of the transfused cell counts were calculated from equation 4 in the preceding report (14):

$$
N_{0} Q=\frac{N}{1-\frac{t}{T}} \text { when } 0 \leq t \leq T \text {, }
$$

where $\mathrm{N}=$ the inagglutinable cell count at time $t$, $\mathrm{T}=$ the potential life span of the transfused cells in days (usually taken as 120), and $t=$ any time between 0 and 120 days after transfusion of the biologically tagged cells. When there has been no loss of transfused cells by random destruction, the $N_{0} Q$ values form a straight horizontal line on the graph. Deviation of the curve of $\mathrm{N}_{0} \mathrm{Q}$ values downward from the horizontal indicates random loss of cells.

Measurement of rate of cell release. When random loss of transfused cells was demonstrated, inspection of the patient's cell counts and consideration of the results of similar experiments prompted the conclusion as to whether the transfusion study had been made during the induction phase of random destruction or whether in the steady state of random destruction (14).

In the steady state of random destruction the expected level of the patient's erythrocytes (assuming a normal rate of erythrocyte release to the circulation and the same rate of loss for cells of both donor and patient) was computed from equation 15 (14):

$$
\mathrm{R}^{\prime}=\mathrm{R}_{\mathbf{0}}\left(\frac{\mathrm{Y}}{\mathrm{Y}+\mathrm{Y}^{\prime}}\right) \text {, }
$$


where $R^{\prime}$ is the expected erythrocyte count of the patient, $R_{0}=$ normal erythrocyte count ( 5 millions per $\mathrm{mm}^{\mathrm{s}}$ ), $\mathrm{Y}=$ the area under the curve made by the $N_{0} Q$ values for the transfused cells, and $Y+Y^{\prime}=$ the area of the rectangle enclosing the curve (see Figure 6 in the preceding paper [14]).

In the induction phase of random destruction the expected curve of the patient's erythrocytes, with the same assumptions as in the preceding paragraph, was computed from equation 27 (14):

$$
R_{\text {ind }}(t)=R_{0}\left(\frac{Z}{Z+Z^{\prime}}\right)
$$

where $R_{\text {ind }}=$ the expected count of the patient's cells at time $t, t=$ the time in days after random loss began, $Z$ and $Z+Z^{\prime}=$ the areas in the graph as constructed in Figure 8 of the preceding paper (14).

In either case the observed values for the patient's erythrocyte counts were compared with those expected and significant discrepancies were interpreted as acceleration or deceleration of the numerical rate of erythrocyte release to the circulation of the patient, briefly referred to as rate of cell release. This relationship is measurable by the method of transfusion survival. Whether the rate of cell release is equal to the rate of erythrogenesis is not directly determinable by the methods employed in these studies.

\section{HEMOLYSIS INDUCED BY IRRADIATION}

\section{Transfusion Survival of Erythrocytes Irradiated in Vitro}

Blood was collected from donors whose cells in previous transfusion experiments had been shown to have normal survival in other recipients. The erythrocytes from this blood were irradiated and then transfused to normal subjects and their rate of loss measured. Two such experiments were made.

Irradiation in vitro with 1000 r. Five hundred ml. of blood was collected in 3.2 per cent sodium citrate solution from a normal donor, belonging to group $\mathrm{O} \mathrm{Rh}_{\mathrm{o}}+$, and stored for 12 hours at $4^{\circ}$ C. It was then placed in a sterile glass jar, $15 \mathrm{~cm}$. in diameter, and irradiated through sterile brown paper with a 200-K.V. X-ray machine, using 0.2-mm. copper and $0.5-\mathrm{mm}$. aluminum filters at a distance of $30 \mathrm{~cm}$. The exposure was $11.1 \mathrm{~min}$ utes, making a total dose of 1000 roentgens. After irradiation the plasma was removed and the erythrocytes were washed once in cold 0.9 per cent sodium chloride solution. The cells were resuspended in saline solution and infused into the vein of the recipient by gravity, without clinical reaction. The recipient, Nor. (Case 1 ), was a 41-yearold woman, belonging to group $\mathrm{A} \mathrm{Rh}_{\mathrm{o}}+$, who had previously been treated for thyrotoxicosis with radioiodine and was presently euthyroid.

The data from this experiment are plotted in Figure 1A. The $N_{0} Q$ values for the inagglutinable cell counts formed a horizontal line, indicating normal survival and no random loss.

Irradiation in vitro with $2000 \mathrm{r}$. Blood from another normal donor, $\mathrm{O} \mathrm{Rh}_{\mathrm{o}}+$, was similarly collected and stored for 18 hours at $4^{\circ} \mathrm{C}$. before transfusion. The blood was irradiated as in the previous experiment, except that the exposure was in two periods of 11.1 minutes each, separated by an interval of five minutes, giving a total of 2,000 roentgens. The cell suspension was transfused to the recipient by gravity without reaction. The recipient, Huf. (Case 2 ), belonged to group A $\mathrm{Rh}_{\mathrm{o}}+$. He was a 25-year-old man who had previously been treated with radioiodine for thyrotoxicosis and was euthyroid.

The results of this study are plotted in Figure $1 B$, where it may be seen that the $N_{0} Q$ values of the inagglutinable cell counts form a horizontal line, indicating normal survival and no random loss of cells.

So far as we are aware, these are the only studies of transfusion survival of erythrocytes subjected to measured amounts of X-rays. No evidence was obtained to indicate that the erythrocytes had been damaged by the procedures. Admittedly the method is crude for calculating the dose of irradiation an erythrocyte receives in circulating through the tissues of a patient undergoing $\mathrm{X}$-ray treatment with cervical carcinoma. It seems conservative to estimate that any one red cell would not receive more than 1,000 roentgens, and certainly not 2,000 roentgens. More extensive work on the effect of in vitro irradiation of dog erythrocytes has been reported by Swisher and Furth (15). 

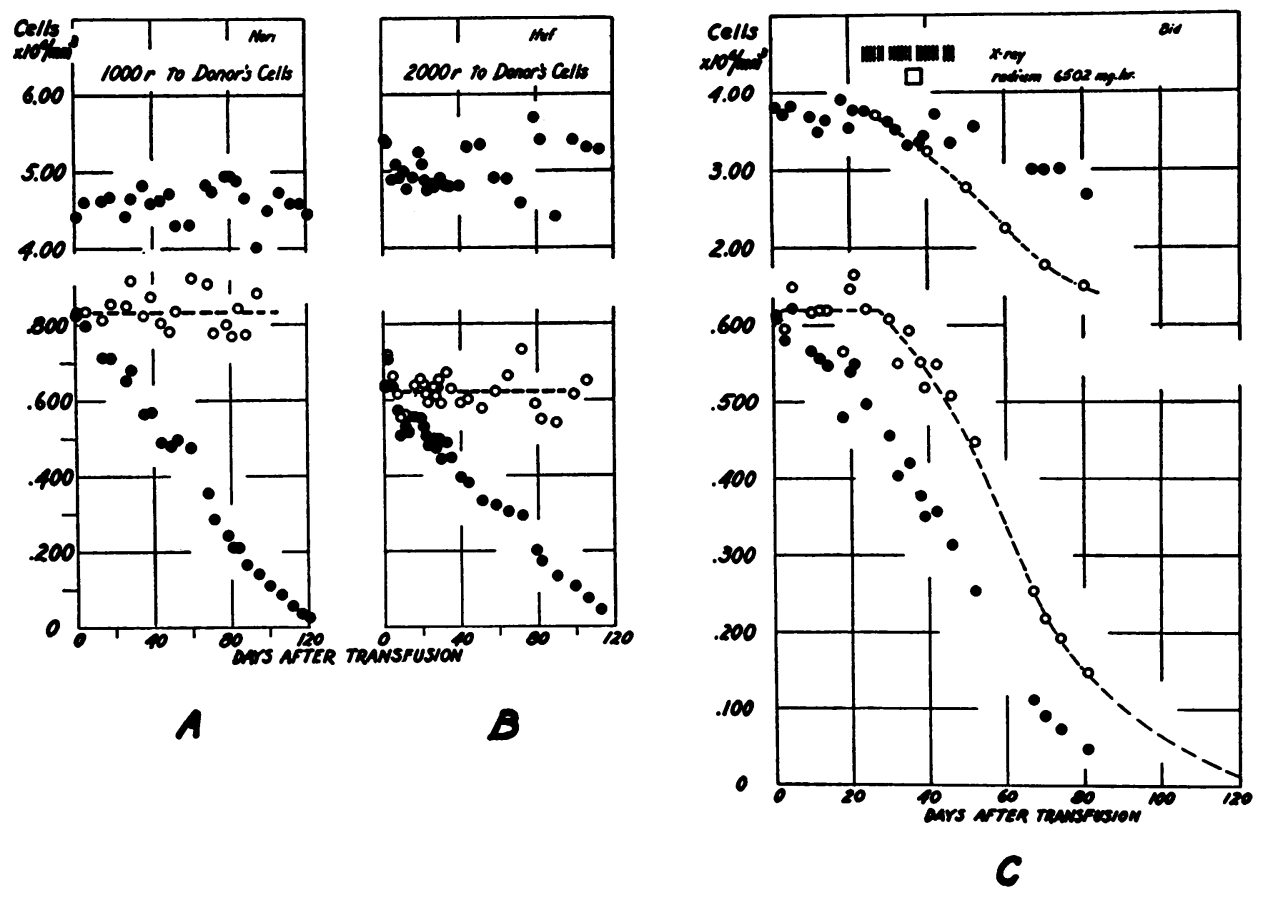

Fig. 1. Random Erythrocyte Destruction in Patients with Carcinoma of the Cervix UtERi after Irradiation with X-Rays aNd Radium

The data are plotted on Cartesian coordinates. In each chart the upper scale deals with erythrocyte counts of the subject; the lower scale pertains to inagglutinable cell counts of the transfused blood. In the lower sections the solid circles represent observed values for inagglutinable cell counts, whereas the open circles are the corresponding $N_{0} Q$ values. The $N_{0} Q$ values are so calculated that they form a horizontal line if there has been no random destruction of cells. Curves formed by $N_{0} Q$ values which deviate from the horizontal indicate random destruction. In the upper sections the solid circles are values for the observed erythrocyte counts of the patient. The open circles, connected with broken lines, form curves calculated for the expected values of the erythrocyte counts of the subject, provided that erythrocyte release proceeds at a normal rate, and that the erythrocytes of the subjects are destroyed in the same manner as the biologically tagged cells. Significant discrepancies between these curves and the observed cell counts of the subject indicate increased or decreased rates of cell release.

Charts 1A and 1B present control studies in which normal fresh blood was exposed in vitro to 1,000 and 2,000 roentgens of $X$-rays and was then transfused to normal subjects. The transfused cells survived normally. The study in Chart 1C shows the transfused cells surviving normally until about 24 days after the beginning of $\mathrm{X}$-ray therapy when random loss commenced. The erythrocyte counts of the subject decreased, but still exceeded the expected values and hence, it is concluded that the rate of cell release increased. Irradiation of Patients with Carcinoma of the
Cervix Uteri

Four women with carcinoma of the cervix uteri were transfused with fresh normal erythrocytes and then treated with $\mathrm{X}$-rays and radium at various intervals after transfusion.

Case 3 (Bid.), group $A R_{\bullet}+, 70$ years old, was admitted with a bloody vaginal discharge of five weeks' duration. The clinical classification of the tumor was Schmitz I, League I. Biopsy showed a well differentiated epidermoid carcinoma of the cervix. She was transfused with fresh normal erythrocytes of group $\mathrm{O} \mathbf{R h}_{\mathrm{o}}+$ which had been washed once in 0.9 per cent sodium chloride solution. The cell suspension of $360 \mathrm{ml}$. was administered by gravity in 35 minutes without clinical reaction.

The graph in Figure 1C contains the data from this transfusion study. The transfused erythrocytes survived normally for about 24 days. Seven days after inception of X-ray therapy random loss of the tagged cells, irrespective of their age, could 
be noted, and continued until the end of the study. The expected values for the subject's cell counts, assuming that the rate of cell release was normal and the subject's cells were destroyed randomly at the same rate as the transfused cells, are shown to be less than the observed cell counts. The conclusion is reached that the rate of release of erythrocytes to the circulation was greater than normal to compensate for the increased loss of cells.

The second patient had a constant level of erythrocyte counts before therapy with $\mathrm{X}$ rays and radium.

Case 4 (Hol.), group O MN Rho,+ 65 years old, had a bloody vaginal discharge for seven months. The clinical classification of the tumor was Schmitz III, League II. The biopsy revealed squamous cell carcinoma of the cervix uteri. The patient was transfused with fresh normal blood of group $\mathrm{O} \mathrm{N} \mathrm{Rh}$. + . The blood was collected from the donor in 3.2 per cent sodium citrate solution making a volume of $579 \mathrm{ml}$. It was transfused to the patient without clinical reaction.

The data from this study, presented in Figure 2A, indicate that the transfused cells survived normally until about 10 days after the beginning of $\mathrm{X}$-ray therapy. Subsequently there was evidence of random loss of the donor's erythrocytes. Comparison of the expected erythrocyte counts of the subject with those observed led to the conclusion that the rate of cell release slightly exceeded the normal from the 24th to the 60th day after transfusion and thereafter there was rapid acceleration. The acceleration occurred between 12 and 20 days after cessation of therapy.
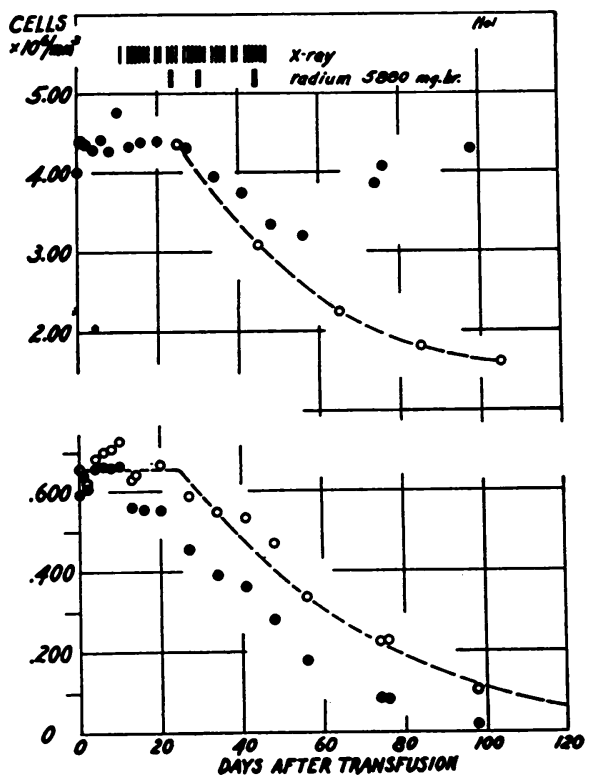

A.
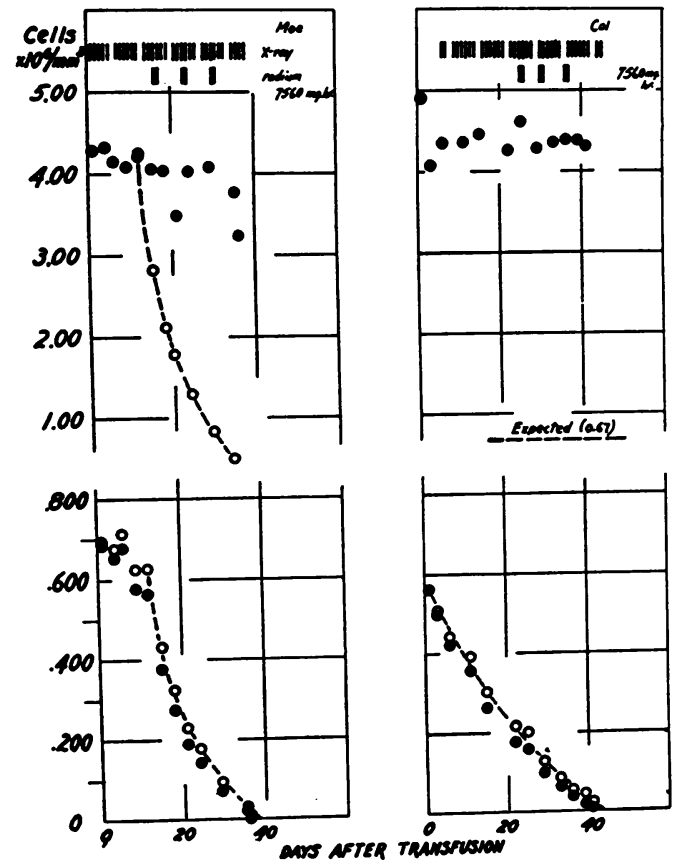

B.

c.

Fig. 2. Random Destruction of Erythrocytes in Patients with Carcinoma of the Cervix Uteri Treated with X-RAYs aNd Radium

The construction and interpretation of the charts is similar to that in Figure 1 . In $2 \mathrm{~A}$ and $2 \mathrm{~B}$ the data indicate that an induction phase of random destruction occurred during $\mathrm{X}$-ray therapy. In both cases during $\mathrm{X}$-ray therapy the erythrocyte counts of the subject decreased, but not at the rate to be expected with a normal cell release rate. It was concluded, therefore, that the rate of cell release was increased as a response to the accelerated destruction of cells.

In chart 2C there was random destruction of transfused erythrocytes before irradiation was begun. Since the patient's mean erythrocyte count was about 4.5 millions per mm.', it was inferred that the experiment was conducted during a steady state of random destruction. The expected erythrocyte level of the patient was calculated as 0.67 million per mm. ${ }^{2}$ These data indicate a rate of cell release of almost seven times the normal. 


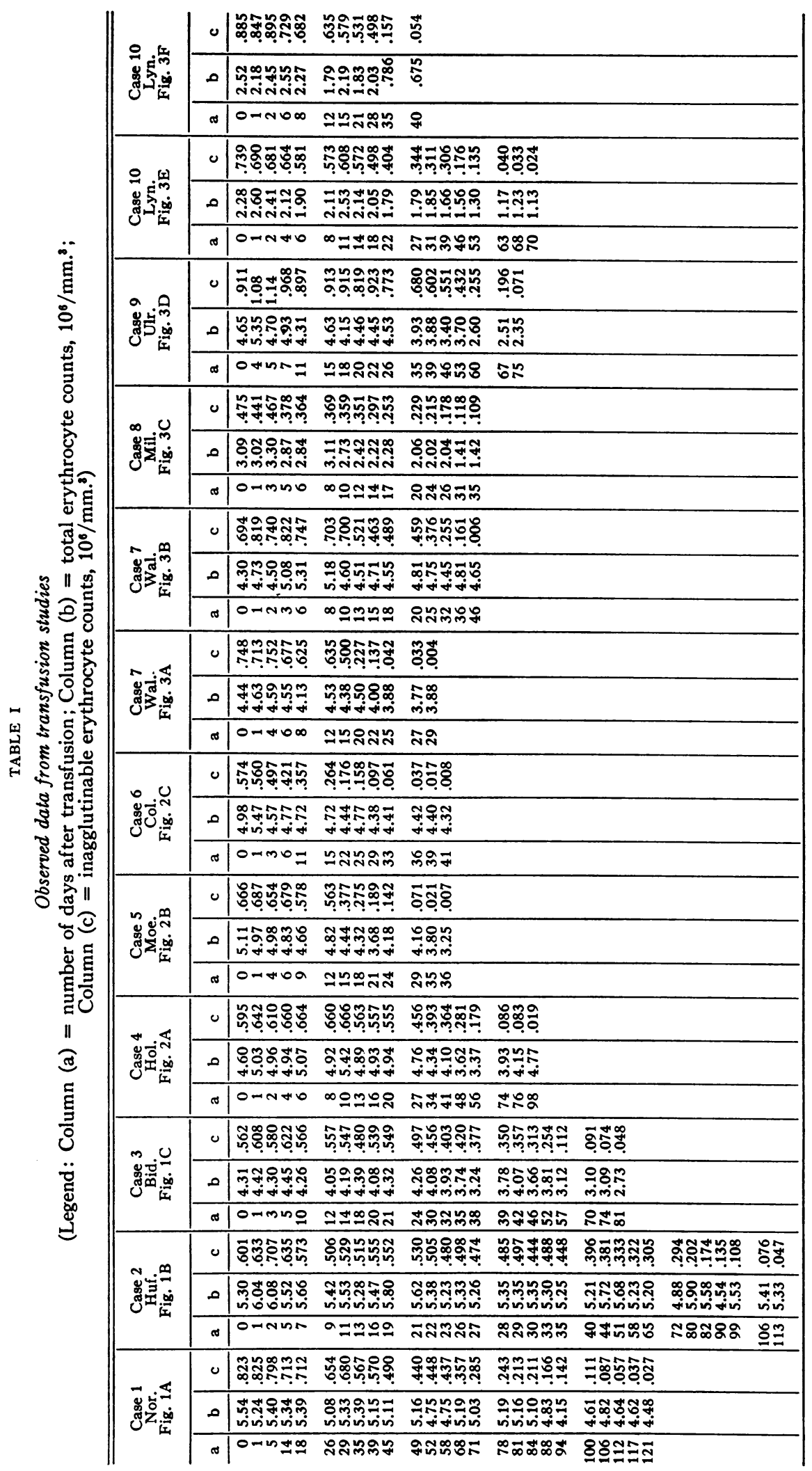


The third patient had a normal erythrocyte level before therapy with $\mathrm{X}$ rays and radium.

Case 5 (Moe.), group A $\mathrm{Rh}_{\mathrm{o}}+, 30$ years old, had had vaginal bleeding for six months. The tumor was classified clinically as Schmitz IV, League IV, and biopsy showed a highly undifferentiated adenocarcinoma of the cervix uteri. The patient was transfused in 27 minutes with $355 \mathrm{ml}$. of a suspension of erythrocytes belonging to group $\mathrm{O} \mathrm{Rh}_{\mathrm{o}}+$. The blood had been collected in 3.2 per cent sodium citrate solution, the cells separated from the plasma by centrifugation and then washed once in 0.9 per cent sodium chloride solution. On the 38th day after transfusion both the direct and indirect Coombs' tests were negative. X-ray therapy was begun the day after transfusion.

The graphs in Figure 2B show that random destruction of the transfused erythrocytes began about 10 days after inception of X-ray therapy. There was only a slight decrease in the cell counts of the subject although the expected values, computed for normal rate of cell release and loss at the same rate as the transfused cells, dropped precipitously. This calculation is based on the assumption that the random loss of cells was caused by the $\mathrm{X}$-rays, but the period of observation before therapy was too brief and the random loss of transfused cells could be attributed to a hemolytic mechanism acting in a patient in a steady state of random destruction.

The fourth patient, likewise, exhibited consistently normal erythrocyte counts before therapy was begun.

Case 6 (Col.), group $\mathrm{A} \mathrm{Rh}_{\mathrm{o}}+, 32$ years old, had a history of vaginal discharge and moderate intermittent bleeding. The tumor was classified as Schmitz III, League III. The biopsy showed a poorly differentiated adenocarcinoma of the cervix uteri. Blood was collected from a normal donor of group $\mathrm{O} \mathrm{Rh}_{0}+$ and stored for 12 hours at $4^{\circ} \mathrm{C}$. in 3.2 per cent sodium citrate solution. The cells were separated from the plasma, washed once in cold 0.9 per cent sodium chloride solution, and transfused in 20 minutes.

The data, graphed in Figure 2C, show that random destruction of transfused cells began before the inception of X-ray therapy. Therefore, it was assumed that the patient was in a steady state of random destruction and her expected erythrocyte level was computed on that hypothesis. Comparison of the observed cell level with that expected leads to the conclusion that the rate of cell release was about seven times the normal.

\section{SPONTANEOUS HEMOLYSIS IN MALIGNANCIES}

The finding of random destruction of normal erythrocytes before X-ray therapy in the patient represented in Figure 2C prompted study of patients with other forms of malignancy not subjected to irradiation. The total mass of malignant tissue in the patients with carcinoma of the cervix uteri was estimated to be small as compared with the patients selected for this phase of the study with widespread metastases and anemia.

Carcinoma of the breast. A patient with this condition was studied in whom there was widespread metastases and a slight anemia.

Case 7 (Wal.), group $\mathrm{A} \mathrm{Rh}_{\mathrm{o}}+$, a woman of 45 years, had had a radical mastectomy on the right side for carcinoma of the breast. Carcinomatosis, involving the left pleural space and most of the bones, had been present for about 12 months. The patient was bedfast because of the collapse of several cervical vertebrae. Blood studies showed: hemoglobin, $12.0 \mathrm{Gm}$. per $100 \mathrm{ml}$.; erythrocytes, 3.95 millions per $\mathrm{mm}^{3}$; leukocytes, 5400 per mm. ${ }^{3}$; erythrocyte sedimentation rate (Westergren), $52 \mathrm{~mm}$. in 60 min.; reticulocytes, 1.8 per cent; platelets, 178,000 per $\mathrm{mm}^{2}$ The first transfusion of normal group $\mathrm{O} \mathrm{Rh}_{\mathrm{o}}+$ erythrocytes was in a volume of $347 \mathrm{ml}$. The plasma had been decanted after storage for 12 hours at $4^{\circ} \mathrm{C}$. in ACD solution. The injection required 29 minutes and was not attended by clinical reaction. During the first study the patient received $300 \mathrm{mg}$. of testosterone propionate per week. The second transfusion was administered with blood from another norml donor of the same group and type as the first. During the subsequent period of study only symptomatic therapy was given.

The data for the two study periods are graphed in Figures $3 \mathrm{~A}$ and $3 \mathrm{~B}$. In both there was rapid random loss of the transfused erythrocytes at substantially similar rates. Since the subject's erythrocyte counts remained constant, it was assumed that she was in a steady state of random destruction. Computation of the expected erythrocyte levels of the patient, on the assumption that her cells were being destroyed at the same rate as the normal erythrocytes, led to the conclusion that the rate of cell release was four to six times the normal.

Adenocarcinoma of the rectum. One example of this disorder was the subject of study.

Case 8 (Mil.), group $\mathrm{A} \mathrm{Rh}_{\mathrm{o}}+$, a 70 -year-old woman, had adenocarcinoma of the rectum which involved the local nodes and extended onto the sacrum. Eighteen days before the study the blood findings were: hemoglobin, $10.5 \mathrm{Gm}$. per $100 \mathrm{ml}$; erythrocytes, 3.65 millions per mm. ; leukocytes, 13,000 per mm. ${ }^{3}$ of which 62 per cent 


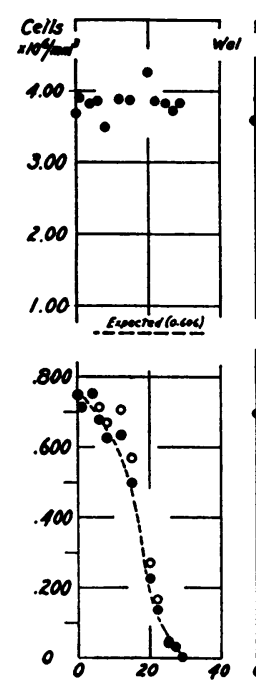

A.
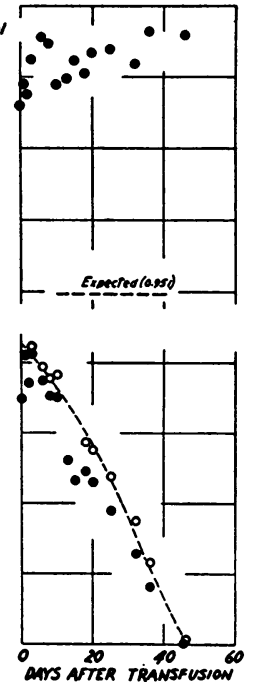

B.
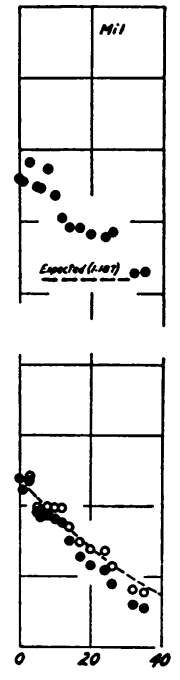

c.
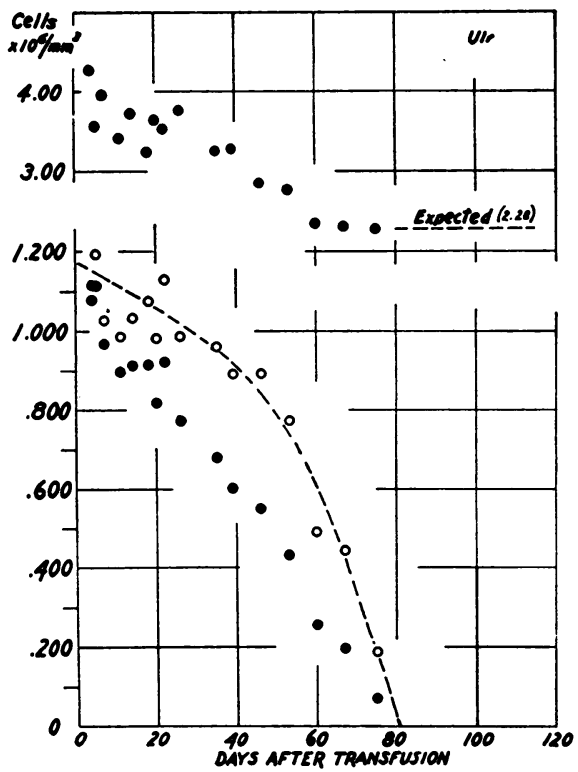

D.
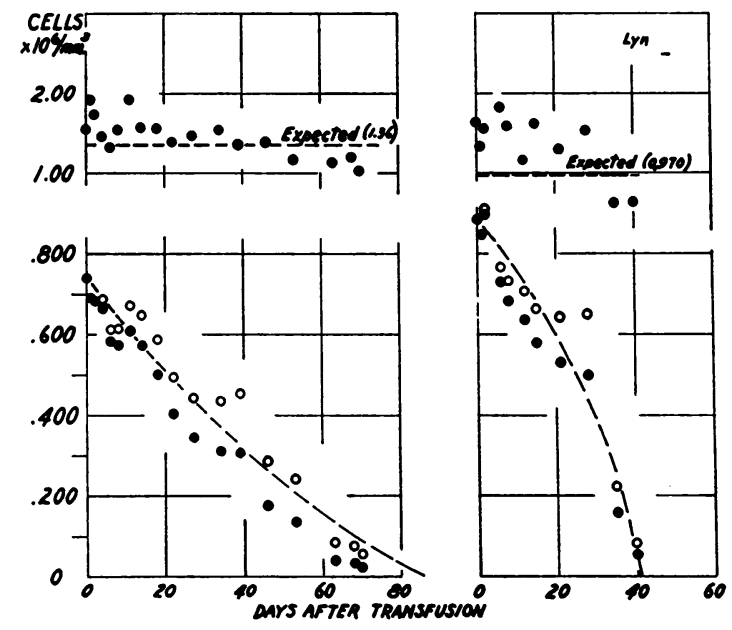

E

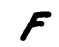

Fig. 3. Random Destruction of Erythrocytes in Patients with Malignant Disease WITHOUT TREATMENT

The charts are constructed and interpreted as in the preceding figures. The conditions of the experiments were such that all patients were considered in the steady state of random destruction. In all there was malignant disease extensively involving the bone marrow. In charts $3 \mathrm{~A}$ and $3 \mathrm{~B}$ are the data of two successive transfusions of biologically tagged cells from different donors to the same subject with carcinoma of the breast and bony metastases. The expected levels of the subject's cell counts were calculatd as 0.60 and 0.95 million per mm.", whereas the observed cell counts were about 4.0 and 4.3 millions. These imply cell production rates of 6.6 and 4.5 times the normal.

The patient represented in chart $3 \mathrm{C}$ had carcinoma of the rectum with metastasis to bone. The transfused cells underwent random loss. The expected erythrocyte level of the subject was estimated to be 1.18 millions per mm. ${ }^{2}$ During the study the observed cell level decreased to that value, at which time death occurred. 
were segmented neutrophiles, 2 per cent eosinophiles, 32 per cent lymphocytes, and 4 per cent monocytes. The total serum proteins were $7.47 \mathrm{Gm}$. per $100 \mathrm{ml}$. of which 4.23 $\mathrm{Gm}$. were albumin and $3.24 \mathrm{Gm}$. were globulin. Eleven days before the study an exploratory laparotomy and colostomy were performed, during which $1,000 \mathrm{ml}$. of blood of homologous group was transfused. For the study, the patient was transfused with normal group $\mathrm{O} \mathrm{Rh}_{\mathrm{o}}+$ blood. The blood was collected in 3.2 per cent sodium citrate solution, centrifuged, and the cells washed once with cold 0.9 per cent sodium chloride solution. A saline suspension of cells of $370 \mathrm{ml}$. was transfused in 45 minutes without clinical reaction. At no time during the study was there evidence of melena. The condition of the patient deteriorated and she died on the 38th day after transfusion.

Necropsy revealed adenocarcinoma of the rectum with extensive regional and distant metastases. There was evidence of terminal infection. The spleen weighed 650 $\mathrm{Gm}$. and contained areas of necrosis and multiple centers of hematopoiesis with clusters of myeloblasts, normoblasts, and megaloblasts. Hemosiderin was present in crystals and macrophages. There were centers of hematopoiesis and hemosiderin collections in the liver. Much of the bone marrow was replaced with carcinoma cells, but there were many islands of erythroid and myeloid activity.

The data for the short study are graphed in Figure 3C. They show that random destruction of transfused erythrocytes was present from the beginning of the study and the percentage rate continued constant until the end. The erythrocyte counts of the patient diminished, but did not reach a sufficiently low level to coincide with the expected values, until just before death. Previously the rate of cell release was faster than normal.

Multiple myeloma. Three transfusion studies were made on two patients with this disorder. The study in the first patient was continued until death.

Case 9 (Ulr.), group AB Rho-negative, a woman of 61 years, had had backache and weight loss for six months. Bence-Jones protein was found in the urine. The blood findings were: hemoglobin, $12 \mathrm{Gm}$. per $100 \mathrm{ml}$; ; erythrocytes, 4.39 millions per mm. ${ }^{3}$; leukocytes 8,000 per $\mathrm{mm}^{3}$ with normal proportions of cells. The serum protein concentrations were normal. Initially the blood urea nitrogen and creatinine were normal but, as the study progressed, maxima of $55 \mathrm{mg}$. of blood urea nitrogen per $100 \mathrm{ml}$. and creatinine of $3.0 \mathrm{mg}$. were attained. The values for calcium, phosphorus, and phosphatase of the blood were normal. Sternal puncture revealed many typical myeloma cells. X-ray films of the bones revealed numerous osteolytic lesions in the skull, thorax, lumbar spine, and pelvis, with collapse of the second lumbar vertebra. The treatment was symptomatic.

Normal group $\mathrm{O} \mathrm{Rh}_{\mathrm{o}}$-negative blood was collected in ACD solution, stored for four hours at $4^{\circ} \mathrm{C}$., centrifuged, the plasma removed, and the erythrocytes washed once in cold 0.9 per cent sodium chloride solution. A saline suspension of cells of $308 \mathrm{ml}$. was transfused in 17 minutes without reaction. The direct Coombs' test on her erythrocytes was negative. The indirect Coombs' test, using her serum and the erythrocytes of the donor, was likewise negative.

Death occurred on the 78th day after transfusion. Necropsy showed extensive distribution of myeloma cells in the skeletal system. There was hyperplasia of the erythroid elements and a relative decrease of the myeloid tissue in the bone marrow. The liver and spleen were normal.

The data are graphed in Figure 3D. During the entire study there was random destruction of the transfused normal cells. With such a rate of cell loss the expected erythrocyte counts of the patients did not correspond with the observed values until the latter had dropped from approximately 4.4 millions per mm. ${ }^{3}$ to 2.2 millions just before death. It is estimated that at the beginning of the study the rate of cell release was approximately twice the normal. The decrease of the cell counts of the patient to the expected level just before death is similar to the finding in the patient represented in Figure 3C.

A second patient with multiple myeloma was the subject of two transfusion experiments.

Case 10 (Lyn.), group $\mathrm{A} \mathrm{Rh}_{\mathrm{o}}+$, a woman of 59 years, had back pain for three months. The blood findings were: hemoglobin $8.5 \mathrm{Gm}$. per $100 \mathrm{ml}$; erythrocytes, 2.70 millions per mm. ; leukocytes, 4,400 per mm. ${ }^{3}$ of which 60 per cent neutrophiles, 30 per cent lymphocytes, and 10 per cent monocytes. The concentration of serum proteins

Data from a patient with multiple myeloma are presented in $3 \mathrm{D}$. The transfused cells were lost at random. Before transfusion her erythrocyte count was about 4.0 million per mm. ${ }^{2}$ at which time a cell release rate of 1.7 times normal was estimated. During the study her condition deteriorated and the erythrocyte counts decreased to the expected level just before death.

Charts $3 \mathrm{E}$ and $3 \mathrm{~F}$ present data on a patient with multiple myeloma during two successive transfusions of blood from different donors. Both populations of transfused cells showed random loss. In both cases the expected erythrocyte level of the subject, about 1.0 million per mm.', coincided with the observed values so that, even at the low level, the rate of cell release was apparently normal. 
was $11.12 \mathrm{Gm}$. per $100 \mathrm{ml}$. of which albumin was 2.54 $\mathrm{Gm}$. and globulin, $8.54 \mathrm{Gm}$. The serum calcium was 14.0 mg. per $100 \mathrm{ml}$. and the phosphorus $4.4 \mathrm{mg}$. The blood urea nitrogen was $46 \mathrm{mg}$. per $100 \mathrm{ml}$. and the creatinine $2.8 \mathrm{mg}$. X-ray films revealed multiple osteolytic lesions in the skull, spine, pelvis, thorax, and femora. Stains of the aspirated sternal bone marrow showed about 27 per cent cells typical of multiple myeloma.

The patient remained in the hospital six months until her death. Many determinations of blood urea nitrogen were always slightly lower than the initial value. Reticulocyte counts varied from 1.1 per cent to 4.0 per cent. She was treated with urethane without response, except for the alleviation of pain. In the last month of life cobaltous chloride, in doses up to $120 \mathrm{mg}$. daily, were given without change in the hematologic findings. Two transfusion studies were performed. In both the donors were normal persons whose erythrocytes had previously survived normally in other recipients. Both belonged to group $\mathrm{O} \mathrm{Rh}_{0}+$. In one instance blood was collected in 3.2 sodium citrate solution, centrifuged, the cells washed once in 0.9 per cent sodium chloride solution. A cell suspension of $340 \mathrm{ml}$. was transfused in 30 minutes without clinical reaction. The second transfusion was given 40 days before death. The blood was similarly prepared, except that the plasma was decanted and $311 \mathrm{ml}$. of the remaining cells and plasma were transfused in 35 minutes. Before the second transfusion the direct and indirect Coombs' tests were negative. The patient was transfused with $500 \mathrm{ml}$. of blood of homologous group and type on the 53rd, 60th, 65th, 72nd, 73rd, and 81st days of the first study; she received no transfusions during the second study.

At necropsy infiltrations of plasma cells were found in the bone marrow and in the submucosa and muscularis of the esophagus. The bone marrow was pale and oily and was composed primarily of myeloma cells. The spleen weighed $250 \mathrm{Gm}$. and was normal, except for an increased amount of hemosiderin in the phagocytes. There were centers of hematopoieses with myeloid elements, normoblasts, and nucleated red cells. The liver was normal, except for the presence of hemosiderin in the hepatic cells.

The data from both transfusion studies are presented in Figures $3 \mathrm{E}$ and $3 \mathrm{~F}$. Random loss of transfused erythrocytes was demonstrated in both, with a faster rate in the second than in the first transfusion. The observed values for the patient's erythrocytes are valid for analysis only for the first 50 days of the first transfusion study. During this period the observed cell level coincided with that expected, on the assumption of normal rate of cell release and a random loss of both populations of cells at similar rates. Despite the extensive replacement of erythroid elements in the bone marrow by myeloma tissue, sufficient erythropoietic tissue must have remained to produce normal-sized crops of erythrocytes. Unlike the other patient, however, enough bone marrow was not available to permit acceleration of erythropoiesis so that a steady state of the erythrocyte level could be maintained at approximately normal. The data obtained during the second study cannot be analyzed because of the presence of a relatively high percentage of transfused cells of homologous group.

\section{DISCUSSION}

In four women with relatively localized carcinoma of the cervix uteri, the erythrocyte level was approximately normal before they were subjected to irradiation in the pelvic region. From the data obtained by transfusion of normal erythrocytes, it could be deduced that three of the four were in a normal steady state of erythrocyte production and loss by aging, whereas in the fourth the normal erythrocyte level was apparently maintained by an accelerated rate of erythrocyte release, despite rather rapid loss of cells by random destruction. In the three subjects with no initial random loss of cells, random destruction of the transfused erythrocytes occurred after irradiation with $X$ rays for 7 to 10 days. Since in vitro irradiation of normal erythrocytes showed normal survival in normal recipients, it is inferred that the action of $\mathrm{X}$ rays was to initiate some hemolytic mechanism, either in normal tissue of the patient or in the carcinoma cells. These experiments cannot differentiate between the effects on normal tissue and carcinoma because no patients could be found for study who received comparable doses of radiation without having malignancy. Our methods of analysis show that despite the fact that the erythrocyte levels of the patients diminished during X-ray therapy, the rate of cell release actually increased to compensate partially for the increased loss of red cells. There may have been local depression of erythropoiesis from irradiation, but apparently, adequate erythrogenic tissue was unaffected so that partial compensatory acceleration of cell release was possible.

In four patients, selected for study because of extensive involvement of the bone marrow by malignancy (one carcinoma of the breast, one carcinoma of the rectum, two with multiple myeloma), a mechanism was demonstrated which destroyed 
normal transfused erythrocytes at random, and presumably acted similarly on the patients' own cells. In three of these the rate of cell release was greater than normal, maintaining a normal erythrocyte level in two and declining cell level in the third. In one patient with extreme infiltration of the bone marrow with myeloma cells, a steady state of oligocythemia was maintained by a normal rate of cell release in the face of a random destructive mechanism. The fact that the cell release rate was not accelerated could be interpreted as evidence of a degree of myelophthisic anemia, but the greatest contribution to the oligocythemia in this case was the random loss of erythrocytes.

The findings in our studies seem to be in harmony with the report of Vaughan (16) who noted an increase in the total quantity of active bone marrow and hyperplasia of the hemopoietic elements in patients with carcinomatosis and anemia. The in vitro studies of other workers $(3,4)$ have clearly shown that carcinomatous tissue extracts are hemolytic and furnish a possible explanation for the spontaneous random destructive mechanism observed in our studies.

\section{SUMMARY}

Fresh normal erythrocytes, irradiated in vitro with 1,000 and 2,000 roentgens, survived normally when transfused to normal recipients.

Three patients with carcinoma of the cervix uteri, with normal erythrocyte levels and normal rates of cell loss, developed a random destructive mechanism for transfused cells from 7 to 10 days after X-ray therapy was begun. They developed various grades of oligocythemia which were ascribed to excessive loss of erythrocytes from random destruction, despite actual acceleration of the rate of erythrocyte release to the circulation. A fourth patient with the same disease was demonstrated to have a spontaneous random destructive mechanism for transfused cells, but she maintained a normal erythrocyte level by accelerated rate of cell release. It is concluded that $X$ rays act on either normal tissue or carcinoma cells to produce a hemolytic factor.

Four patients, selected for study because of extensive involvement of the bone marrow by malignant disease (one carcinoma of the breast, one carcinoma of the rectum, two with multiple mye- loma), exhibited a spontaneous random destructive mechanism for transfused cells and, presumably, for their own erythrocytes. Two had normal erythrocyte levels, maintained by accelerated rate of cell release. Another had oligocythemia with an accelerated rate of cell release. A fourth maintained for many days erythrocyte counts of about 1.5 millions per mm. ${ }^{3}$ with a calculated normal rate of cell release. This patient had the most extensive infiltration of the bone marrow and the lack of acceleration of the cell release rate is the only evidence in these studies for a possible myelophthisic factor in anemia.

\section{CONCLUSIONS}

1. In vitro $\mathrm{X}$ radiation of normal human erythrocytes with 2,000 roentgens, or less, did not affect their survival when transfused to normal recipients.

2. In vivo irradiation of normal and/or carcinomatous tissue initiated a hemolytic mechanism in patients with cancer of the cervix uteri.

3. An abnormal hemolytic mechanism occurred spontaneously in some patients with cancer.

4. The oligocythemia in eight patients with cancer was caused by hemolysis.

\section{ACKNOWLEDGMENT}

We wish to thank Dr. William C. Keettel for aid in the study of the patients with carcinoma of the cervix uteri and Dr. Titus C. Evans for irradiating the normal erythrocytes.

\section{REFERENCES}

1. Sheets, R. F., Hamilton, H. E., DeGowin, E. L., Keettel, W. C., and Janney, C. D., Evidence for a hemolytic anemia exacerbated by $x$-irradiation in patients with cancer. J. Lab. \& Clin. Med., 1951, 38, 951.

2. Wintrobe, M. M., Clinical Hematology, ed. 3, Philadelphia, Lea \& Febiger, 1951.

3. Weil, R., Hemolytic properties of organ and tumor extracts. J. Med. Research, 1907, 16, 287.

4. Gross, L., Hemolytic action of mouse mammary carcinoma filtrate on mouse erythrocytes in vitro. Proc. Soc. Exper. Biol. \& Med., 1947, 65, 292.

5. Gross, L., Destructive action of human cancer extracts on red blood cells in vitro. Proc. Soc. Exper. Biol. \& Med., 1949, 70, 656.

6. Ross, J. F., Crockett, C. L., Jr., and Emerson, C. P., The mechanism of anemia in leukemia and malignant lymphoma. J. Clin. Invest., 1951, 30, 668. 
7. Schwartz, S., Katz, E. J., Porter, L. M., Jacobson, L. O., and Watson, C. J., Studies of the hemolytic effect of radiation. Atomic Energy Commission Report CH3760, 1946.

8. Davis, R. W., Dole, N., Izzo, M. J., and Young, L. E., Hemolytic effect of radiation. Observations on renal bile fistula dogs subjected to total body radiation and on human blood irradiated in vitro. J. Lab. \& Clin. Med., 1950, 35, 528.

9. Heilmeyer, L., Klinische Farbmessungen. IV. (Mitteilung) Die Harnfarbe in ihrer physiologischen und klinischen Bedeutung. D. Die febrile Hyperchromurie. Die Harnfarbe bei perniziöser Anämie und Polycythämie, sowie beim Diabetes mellitus. Die Harnfarbstoffausscheidung bei Nierenkrankheiten. Ztschr. f. d. ges. exper. Med., 1928, 60, 626. Cited by Atomic Energy Comm. CH3760, p. 12.

10. Ting, T. P., and Zirkle, R. E., The nature and cause of the hemolysis produced by X-rays. J. Cell. \& Comp. Physiol., 1940, 16, 189.

11. Fricke, H., and Petersen, B. W., The relation of clinical, colloidal and biological effects of roentgen rays of different wave lengths to the ionization which they produce in air. I. Action of roentgen rays on solutions of oxyhemoglobin in water. Am. J. Roentgenol., 1927, 17, 611.

12. DeGowin, E. L., Sheets, R. F., and Hamilton, H. E., Studies with inagglutinable erythrocyte counts. I. A method for measurement of net gain or deficit of red cells in the human subject. J. Clin. Invest., 1950, 29, 693.

13. Sheets, R. F., Janney, C. D., Hamilton, H. E., and DeGowin, E. L., Studies with inagglutinable erythrocyte counts. III. Kinetics of erythrocyte destruction in human beings. J. Clin. Invest., 1951, 30, 1272.

14. DeGowin, E. L., Ellis, J. A., Sheets, R. F., Hamilton, H. E., and Janney, C. D., Studies with inagglutinable erythrocyte counts. IV. Graphic analyses of rates of production and destruction of human erythrocytes. J. Clin. Invest., 1954, 33, 163.

15. Swisher, A. N., and Furth, F. W., Hemolytic effect of X-radiation: survival of normal erythrocytes transfused to irradiated dogs. Am. J. Med., 1953, 14, 530.

16. Vaughan, J. M., Leuco-erythroblastic anaemia. J. Path. \& Bact., 1936, 42, 541. 